\title{
Performance of different biomarkers for the management of hepatocellular carcinoma
}

\author{
Ángela Rojas', Yolanda Sánchez-Torrijos², Antonio Gil-Gómez¹, Chang-Hai Liu1', Clara Rodríguez-Rivas', \\ María Teresa Ferrer², Manuel Romero-Gómez ${ }^{1}$ \\ ${ }^{1}$ Traslational and Clinical Research Laboratory - Liver and Digestive Diseases - CIBERehd, Institute of Biomedicine of Seville, Virgen del \\ Rocío University Hospital/CSIC/University of Seville, Seville 41013, Spain. \\ ${ }^{2}$ Unit for the Clinical Management of Digestive Diseases, Virgen del Rocio University Hospital, University of Seville, Seville 41013, \\ Spain.
}

Correspondence to: Prof. Manuel Romero-Gómez, Head of Unit for the Clinical Management of Digestive Diseases, CIBERehd, Institute of Biomedicine of Seville, Virgen del Rocío University Hospital/CSIC/University of Seville, Seville 41013, Spain.

E-mail:mromerogomez@us.es

How to cite this article: Rojas Á, Sánchez-Torrijos Y, Gil-Gómez A, Liu CH, Rodríguez-Rivas C, Ferrer MT, Romero-Gómez M. Performance of different biomarkers for the management of hepatocellular carcinoma. Hepatoma Res 2018;4:31.

http://dx.doi.org/10.20517/2394-5079.2018.60

Received: 15 May 2018 First Decision: 7 Jun 2018 Revised: 21 Jun 2018 Accepted: 22 Jun 2018 Published: 6 Jul 2018

Science Editor: Guang-Wen Cao Copy Editor: Jun-Yao Li Production Editor: Huan-Liang Wu

\begin{abstract}
Hepatocellular carcinoma (HCC) is the fifth most common cancer worldwide and the second cause of cancer related death due to latent liver disease, late diagnosis and non-available therapeutic treatment. Liver biopsy is still the gold standard in order to know the molecular biology of the tumor, its behaviour and invasive characteristics. Conventional diagnosis methods for HCC detection include imaging and serological tests with low sensitivity and specificity. In this review, we focus on the potential utility of certain serum biomarkers and a new approach, "liquid biopsy", in the management of HCC patients.
\end{abstract}

Keywords: Hepatocellular carcinoma, liver biopsy, conventional diagnostic methods, management

\section{INTRODUCTION}

Liver cancer, known as well as hepatocellular carcinoma (HCC), is the fifth most common type of cancer worldwide and the second cause of cancer related death ${ }^{[1,2]}$. Despite recent development of a diagnostic technics and treatment methods, the prognosis of HCC remains poor. Many patients are diagnosed when HCC is in advanced stages or due to an underlying liver disease, which results in less time for an appropriate treatment ${ }^{[3]}$. 
Table 1. Serum biomarkers for early diagnosis of hepatocelular carcinoma

\begin{tabular}{lcccccc}
\hline Biomarker & Cut-off & Sensibility $\% \mathbf{( 9 5 \%} \mathbf{C l})$ & Specificity $\% \mathbf{( 9 5 \%} \mathbf{C l})$ & AUC & Other utilities & Ref. \\
\hline AFP & 20 & $53(46-59)$ & $90(87-93)$ & 0.8 & Prognosis & {$[9]$} \\
AFP-L3 & 10 & $28(22-34)$ & $97(93-100)$ & 0.66 & Prognosis & {$[9]$} \\
DCP & 150 & $61(55-68)$ & $70(65-74)$ & 0.72 & Prognosis & {$[9]$} \\
GPC3 & $0-003-300$ & $53(0.49-0.57)$ & $77(0.74-0.81)$ & 0.82 & Treatment & {$[28,33]$} \\
\hline
\end{tabular}

AFP: alpha-fetoprotein; DCP: des-gamma-carboxy prothrombin; GPC3: glypican-3; AUC: area under the curve; Cl: confidence interval

Conventional diagnosis methods for HCC detection include imaging and serological test with low sensitivity and specificity ${ }^{[4]}$. In this review we provide a briefly outline of HCC serological biomarkers [Table 1] and highlight the recent development of circulating cancer byproducts detection: liquid biopsy.

\section{CONVENTIONAL SERUM TUMOR MARKERS}

\section{Alpha-fetoprotein}

Alpha-fetoprotein (AFP) is a glycoprotein that transports a great variety of molecules, and it is usually produced during fetal and neonatal development by the liver, yolk sac and gastrointestinal tract. Once it reaches its maximum concentration in the second trimester, its levels decrease until it is only detected in small amounts in serum ${ }^{[5]}$. Elevated levels of AFP in adulthood can be related to malignant diseases, such as HCC and other gastrointestinal, pancreatic, biliary, nonseminomatous germ-cell testicular, and germ cell ovarian cancers $^{[6]}$. However, an increase of serum AFP levels can be expected in non-neoplasic conditions, such as pregnancy, cirrhosis $(11 \%-47 \%)$ or acute hepatitis $(30 \%-50 \%)^{[7]}$.

If we use a cut-off of $20 \mathrm{ng} / \mathrm{mL}$, the sensitivity and specificity values of AFP 12 months prior to the time of HCC diagnosis are $47 \%$ and $75 \%$ respectively, while at the time of diagnosis, those values rise to $61 \%$ in the case of sensitivity and $81 \%$ in the specifity variable ${ }^{[8]}$. However, if we increase the cut-off to $200 \mathrm{ng} / \mathrm{mL}$, we improve the specificity to $100 \%$, at the expense of decreasing sensitivity.

On the other hand, Marrero et al..$^{[9]}$, carried out a case-control study among patients with compensated cirrhosis and patients with HCC [both hepatitis C virus ( $\mathrm{HCV}+)$ ], concluding that AFP had the best area under the receiver operating characteristic (ROC), curve [0.80, 95\% confidence interval (CI): 0.77-0.84], with a cut-off of $10.9 \mathrm{ng} / \mathrm{mL}$, for early stage HCC (BCLC stages 0 and A).

At present, AFP is used as a complementary biomarker to ultrasonography (US) for HCC surveillance, although clinical guidelines only recommend the last on $e^{[10,11]}$. However, according to a recently published meta-analysis ${ }^{[12]}$, where 38 observational cohort studies that evaluated surveillance in patients with cirrhosis were included, it was observed that the use of US plus AFP improves detection of early-stage HCC compared with no surveillance [odds ratio $(\mathrm{OR})=2.16$ (95\% CI: 1.80-2.60)], while US alone had an OR of 2.04 (95\% CI: 1.55-2.68); at the same time, US plus AFP had a risk ratio for improving survival of 1.86 (95\% CI: 1.761.97), while US alone had a slightly lower risk ratio of 1.75 (95\% CI: 1.56-1.98), although it was not statistically significant. There were no studies that directly compared US alone versus US plus AFP, and only 4 studies used US alone, while the rest of the studies relied on US and AFP at 6-month intervals.

Finally, in addition to early diagnosis, AFP can also predict the survival after liver transplantation (LT) in patients with HCC, as shown by She et al. ${ }^{[13]}$ in a study conducted in 250 patients, in which survival is less than 5 years post-LT if AFP levels are higher than $400 \mathrm{ng} / \mathrm{mL}[66 \% v s .85 \%(\mathrm{AFP}<10 \mathrm{ng} / \mathrm{mL}), P=0.029]$.

Serum AFP level is correlated with the tumor size. In fact, $80 \%$ of small HCC $(<2 \mathrm{~cm})$ do not show high levels of serum AFP. In the other hand, AFP levels can be increased in patients with chronic liver disease with a degree of hepatocytes regeneration such as HCV-infection that shows a high level of AFP in absence 
of malignancy ${ }^{[14]}$. For these reasons, some additional biomarkers for the diagnosis of HCC are needed to improve the sensitivity of AFP and solve these issues.

\section{AFP lectin fraction (AFP-L3)}

AFP exists as three glycoforms, according to its binding capability to Lens culinaris agglutinin lectin (LCA): AFP-L1 (non-binding fraction), AFP-L2 (weak binding fraction), and AFP-L3 (binding fraction) ${ }^{[15]}$. AFP-L1 is increased in chronic hepatitis and liver cirrhosis, whereas AFP-L3, that it's only produced by cancer cells, is specifically increased in $\mathrm{HCC}^{[16]}$.

Regarding the way of measurement, "bound" and "free" AFP isoforms are separated by affinity liquid chromatography. The concentration of bound AFP-L3 is determined fluorometrically, and results are reported as percentage ratio of AFP-L3 to total $\mathrm{AFP}^{[17]}$. On the other hand, the cut-off used is $10 \%$, observing values of $37 \%, 92 \%, 52 \%$ and $85 \%$ for sensitivity, specificity, positive and negative predictive value, respectively ${ }^{[4]}$. These values increase when they are combined with AFP and des-gamma-carboxy prothrombin (DCP) to $77 \%, 59 \%, 32 \%$ and $91 \%$ respectively. However, according to a recently published study, ROC curve analysis showed that the highest specificity and sensitivity of the studied parameters are achieved at cut-offs of $15 \%$ as well as combining AFP-L3 and p53 improves sensitivity to $95.4 \%$ with a specificity of $85 \%{ }^{[18]}$.

Given that the sensitivity is markedly decreased when total concentration of AFP was $<20 \mathrm{ng} / \mathrm{mL}$ (difficulty in detection), Oda et al. ${ }^{[19]}$ found a new way of measurement based on a microchip capillary electrophoresis and liquid-phase binding assay on a $\mu$-ASWako i30 auto analyzer (Wako Pure Chemical Industries, Ltd., Osaka, Japan) that increased the sensitivity compared to the conventional measurement (12.5\% vs. 44.6\%), when using a cut-off value of $5 \%$. Also, none of the benign liver disease patients with both serum AFP $<20 \mathrm{ng} / \mathrm{mL}$ and high sensibility-AFP-L3 $<5 \%$ developed HCC for a median follow-up of 35 months.

Finally, in a meta-analysis that included 12 studies that directly compared the diagnostic accuracy of serum AFP-L3 and AFP in the same population, it was found that, although the specificity for AFP-L3 (0.929) was increased $v s$. AFP (0.856), sensitivity also decreased significantly (0.48 vs. 0.62), with an area under the curve (AUC) of 0.756 vs. 0.863 , respectively ${ }^{[20]}$.

In conclusion, AFP-L3 could be a complementary biomarker for the early diagnosis of HCC, but additional studies that really confirm its usefulness are needed.

\section{Des- $\gamma$-carboxy prothrombin}

Des- $\gamma$-carboxyprothrombin (DCP), also known as prothrombin induced by vitamin K absence II (PIVKA II), is a molecule produced during the process of hepatocytes malignant transformation due to the fact that the vitamin K-dependent carboxylase system becomes impaired, for which it is increased in patients with $\mathrm{HCC}^{[21]}$.

DCP sensitivity and specificity rate at the time of diagnosis were $74 \%$ and $86 \%$, respectively, at a cut off of $40 \mathrm{mAU} / \mathrm{mL}$ and $43 \%$ and $100 \%$, respectively, at a cut off of $150 \mathrm{mAU} / \mathrm{mL}$; while for AFP it was $61 \%$ and $81 \%$ at a cut off of $20 \mathrm{ng} / \mathrm{mL}$ and $22 \%$ and $100 \%$ at a cut off of $200 \mathrm{ng} / \mathrm{mL}$. Sensitivity and specificity were significantly reduced when determined 12 months before diagnosis, being $43 \%$ and $94 \%$, respectively, for DCP and $47 \%$ and $75 \%$, respectively, for $\mathrm{AFP}^{[8]}$.

In a case-control study, where controls were patients with compensated cirrhosis and patients with HCC, it was evaluated DCP and AFP-L3 as biomarkers for the early diagnosis of HCC. AUC for total AFP (0.83, 95\% CI: 0.80-0.85) was similar to DCP (0.81, 95\% CI: 0.78-0.84), but better than for AFP-L3 (0.72, 95\% CI: 0.69-0.75). 
However, in patients with early stage of HCC, AFP showed the best AUC (0.80, 95\% CI: 0.77-0.84) followed by DCP (0.72, 95\% CI: 0.68-0.77) and then AFP-L3 (0.66, 95\% CI: 0.62-0.70). Intermediate-advanced stage of HCC compared to cirrhotic controls showed a highest AUC of DCP (0.89, 95\% CI: 0.86-0.92) compared to total AFP $(0.84,95 \%$ CI: $0.81-0.88)(P=0.01)$, indicating that DCP could be a more useful marker in advanced stages ${ }^{[9]}$. The cut off points used were $20 \mathrm{ng} / \mathrm{mL}$ for AFP, $10 \%$ for AFPL3 and $150 \mathrm{mAU} / \mathrm{mL}$ for DCP.

Nevertheless, there are some important differences between DCP and AFP; DCP is more specific for HCC because the underlying liver disease (e.g., chronic hepatitis C) can lead to an elevation of AFP but not of DCP. The DCP-positive and AFP-negative tumors show greater aggressiveness, larger size, less differentiation and vascular invasion, and in short, an early recurrence after curative treatments ${ }^{[2,23]}$.

Along these lines, Hamamura et al. ${ }^{[2]}$ compared survival among four groups of similar patients diagnosed with HCC based on AFP and DCP levels (A: AFP below $100 \mathrm{ng} / \mathrm{mL}$ and DCP below $0.0625 \mathrm{AU} / \mathrm{mL}$; B: AFP greater than $100 \mathrm{ng} / \mathrm{mL}$ and DCP below $0.0625 \mathrm{AU} / \mathrm{mL}$; C: AFP below $100 \mathrm{ng} / \mathrm{mL}$ and DCP above $0.0625 \mathrm{AU} / \mathrm{mL}$; D: AFP greater than $100 \mathrm{ng} / \mathrm{mL}$ and DCP above $0.0625 \mathrm{AU} / \mathrm{mL}$ ). The survival rates obtained after 3 years were $73.4 \%, 48.3 \%, 42.7 \%$ and $0 \%$, respectively, while those values at 5 years were $53.5 \%, 25.9 \%, 0 \%$ and $0 \%$, respectively, in a statistically significant way. Therefore, it can be concluded that patients with high levels of AFP and DCP have a lower survival, as well as those with high DCP only have a worse prognosis than those who do not.

Several studies have suggested that DCP may be involved in cell proliferation of neoplasic cells by acting as a growth factor. This may have important prognostic implications in the future, especially if combined with $\mathrm{AFP}^{[25,26]}$.

\section{Glypican-3}

Glypican-3 (GPC3) is a member of the glypican family of glycosyl-phosphatidylinositol-anchored cell-surface heparan-sulfate proteoglycans. Its levels increase considerably in patients with HCC, while GPC3 is not detected in healthy liver tissue, so it has been identified as an useful tumor marker for HCC diagnosis ${ }^{[27]}$.

Thus, in a recently published meta-analysis, sensitivity and specificity observed were of 0.53 (95\% CI: 0.49 0.57 ) and 0.77 (95\% CI: 0.74-0.81), respectively, with an AUC of $0.82^{[28]}$. In addition, it seems to have a higher sensitivity than AFP, with similar specificity ${ }^{[29]}$, whereas their combination notably increase both sensitivity and specificity $(98.5 \% \text { and } 97.8 \% \text {, respectively })^{[30]}$. On the other hand, GPC3 is detectable in approximately one third of patients with HCC with normal AFP levels ${ }^{[16]}$.

With regard to early diagnosis, Libbrecht et al ${ }^{[31]}$ studied the expression of GPC3 in histopathological samples of HCC with less than or equal to $3 \mathrm{~cm}$ of diameter present in the cirrhotic liver (also analysing non-lesional tissue), low-grade and high-grade dysplastic nodules, and focal nodules of hyperplasia.

Immunohistochemical studies and real time reverse transcriptase-polymerase chain reaction for GPC3 were performed. The expression of GPC3 by both techniques was much higher in small HCC than in cirrhosis and other types of small focal lesions, with a sensitivity and specificity for the diagnosis of HCC in small focal lesions of 0.77 and 0.96 , respectively, in resected cases, and 0.83 and 1, respectively, for needle biopsies. This may be due to the stimulation of growth induced by GPC3, which upregulates the autocrine/paracrine canonical Wnt signaling, with a strong increase in its expression in the transition from premalignant lesions to small $\mathrm{HCC}^{[32]}$.

Since GPC3 acts as a growth factor in HCC, it could be a potential therapeutic target. Codrituzumab (GC33) is a recombinant, humanized monoclonal antibody that binds to human GPC3 with high affinity. The 
mechanism of the GC33-induced tumor growth inhibition is an antibody-dependent cellular cytotoxicity ${ }^{[33]}$. A phase I study have already shown its tolerability at doses of $20 \mathrm{mg} / \mathrm{kg} /$ week, with little response ${ }^{[34,35]}$. In a randomized placebo-controlled phase II clinical trial conducted subsequently in patients with advanced HCC previously treated, codrituzumab showed no clinical benefit in this population ${ }^{[36]}$.

On the other hand, a GPC3 peptide vaccine that induces peptide-reactive cytotoxic T lymphocytes (CTLs) has also been tested, with a good response in mice, where it has shown to be able to induce a durable regression in $\mathrm{GPC}^{+}{ }^{+}$tumors ${ }^{[37]}$. It has proven to be adequately tolerated in humans, maintaining radiological stability in most patients. In addition, the overall survival was significantly longer (12.2 months, 95\% CI: 6.518.0) in patients with high CTL specific frequencies of GPC3 than in those with low frequencies (8.5 months, 95\% CI: $3.7-13.1 ; P=0.033)^{[38]}$. These results have been subsequently confirmed, but further studies are needed because of the small sample size of these trials ${ }^{[39]}$.

Therefore, new therapies with GPC3 are being developed as a therapeutic target as well as a diagnostic marker, and new studies with a larger sample size are necessary. Finally, biomarkers can also be used to establish new treatment strategies, such as GPC3, but more studies and clinical trials to validate their response and to improve the prognosis are required.

\section{SERPINB3}

SERPINB3 (formerly known as squamous cell carcinoma antigen-1) is a Clade B Serine Protease Inhibitor physiologically found in the spinous and granular layers of normal squamous epithelium, such as tongue, lungs, uterus and others, while become overexpressed by neoplastic cells of these organs ${ }^{[40]}$. Recent studies showed that an aberrant expression of this protein also extends to cancers of other origin such as HCC ${ }^{[41]}$. In fact, while it is not detected in normal hepatocytes, its expression progressively increases during the progression of chronic liver disease and hepatic carcinogenesis.

Furthermore, it was recently confirmed that its expression correlates with that of TGF-B1 and that in fact, SERPINB3 contributes to TGFB1 overexpression and release ${ }^{[42]}$. So, far from its antiprotease activity, and its biomarker possibilities, SERPINB3 was suggested to be an oncoprotein in as much as it protects the cells from apoptosis and induces epithelial-mesenchymal transition, cell invasiveness and proliferation ${ }^{[43]}$. Lastly, it has been found that its overexpression induces chronic unfolded protein response and as a consequence, activation of NF-kB and production of IL- $6^{[44]}$. Besides, a knock-down of SERPINB3 produces an inhibition of tumor growth ${ }^{[45]}$.

In terms of circulating biomarker, it has been described that natural IgMs bind to several tumor antigens and create immunocomplexes, that in this case, showed a better diagnostic performance that the biomarker itself $^{[46]}$. Accordingly, levels of circulating SCCA-IgM have been recently found to increase over time, being predictive of fibrosis progression in patients with chronic hepatitis ${ }^{[47]}$. Furthermore, it has been demonstrated that HCV-infected cirrhotic patients with low levels of serum SCCA-IgM have a decreased risk of developing HCC $^{[48]}$. Eventually, Biasiolo et al. reported that SCCA-IgM, instead of AFP, was associated with the prediction of HCC-free survival in a prospective cohort ${ }^{[44]}$.

\section{LIQUID BIOPSY OF HCC}

"Liquid biopsies" are based on the analysis of tumor components that are shed into the circulation, such as tumor-derived extracellular vesicles, circulating tumor cells (CTCs) or circulating tumor DNA (ctDNA) [Figure 1$]^{[49,50]}$. Numerous studies have shown the potential utility of circulating cancer byproducts detection from which we could extract molecular information about primary tumors ${ }^{[51-54]}$. The liquid biopsy could be conducted in repeated samples providing accessible, accurate and dynamic information to evaluate the tumor status. These novel biomarkers are thought to have great potential and could provide individualized 


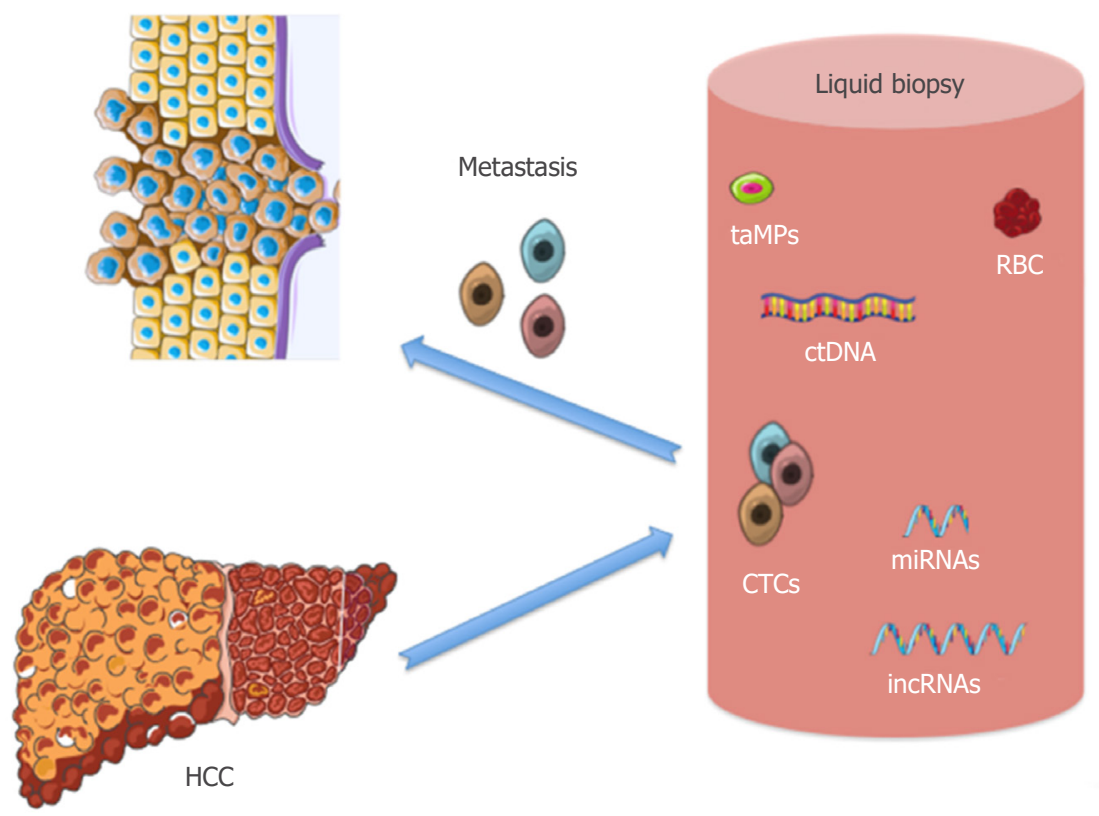

Figure 1. Liquid biopsy of hepatocelular carcinoma (HCC): circulating tumor cells (CTCs), circulating tumor DNA (ctDNA), epigenetic non-coding RNA (miRNAS and IncRNA) and tumor-associated circulating microparticles (taMPs)

decision-making during HCC treatment, including the follow-up period; risk assessment, early cancer detection, treatment response or even prognostic outcome ${ }^{[53-56]}$.

\section{CTCs}

CTCs are spread by tumor malignant cells into peripheral blood in order to reach distal organs and eventually develop metastatic carcinoma ${ }^{[54]}$. Several studies have analysed the role of CTCs as a marker to predict survival, recurrence or treatment response in different kinds of tumors ${ }^{[53,57,58]}$.

The presence of CTCs was reported for the first time in 1869 into the blood of a man with metastatic cancer $^{[59]}$. However, there are some limitations about the use of CTCs due to the incapacity in detecting these cells during the earlier stages of the disease (cells are proportional to tumor volume or aggressive biology behaviour; the larger the tumor, the higher the CTCs-positive rate in the peripheral blood). Unfortunately the frequency of finding CTC in blood is 1 to 10 in a background of millions of blood cells in patients with metastatic disease ${ }^{[60]}$. In the last years, the major challenge for CTCs researchers has been to improve the sensitivity and specificity of CTCs purification in order to perform the molecular characterization of CTCs to ease the development of "accurate medicine"; a cancer management program.

The clinical relevance of CTCs detection in HCC patients has been deeply studied while CTCs isolation and enrichment technologies have emerged. The physical methods are based on the physical properties of CTCs such as size, density, migratory capacity and electric charge ${ }^{[61]}$. The biological methods are focused on antigen-antibody binding against tumor specific biomarkers such as epithelial cell adhesion molecule (EpCAM), CD133, CD90 and human epidermal growth factor receptor2 (Her2) among others ${ }^{[62,63]}$. EpCAM is the most common antigen used for the CTCs isolation; it is the only one clinically validated and approved by the FDA. However, its use has been controversial due to the epithelial-mesenchymal transition (EMT) process that is characterized by the decreasing of epithelial markers expression and the acquisition of mesenchymal profile ${ }^{[64]}$. EpCAM ${ }^{\text {mRNA+ }}$ CTCs enables to differentiate between HCC patients (advance and non-advance stage) and non-HCC with $42.6 \%$ sensitivity and $97 \%$ of specificity (AUC: 0.697 ). When combined with AFP level, the diagnostic value of CTCs was significantly improved and the AUC was 0.857 with a sensitivity of $73.0 \%$ and specificity of $93.4 \%{ }^{[65]}$. 
In addition, these authors showed that most of the patients with an elevated CTC level at the time of disease imaging reassessment showed disease progression after TACE or radiotherapy, whereas patients with stable or deceasing CTC levels showed tumor remission or stable disease ${ }^{[65]}$.

Due to this fact, researchers suggested a combination of antibodies against a variety of surface markers on CTCs in order to avoid the loss of CTCs during the isolation. For this reason, the CTC-chip, based on the microfluidic procedure with higher sensitivity and specificity in CTCs purification ( $99.1 \%$ and specificity $100 \%$ of the CTC-chip across all five cancers; metastatic lung, prostate, pancreatic, breast and colon cancer), is standing out intensely in this field ${ }^{[66]}$.

CTCs detection in HCC patients has been reported in several studies ${ }^{[67,68]}$. The numbers of CTCs were closely correlated with portal vein thrombosis, tumor infiltration, prognosis and Child-Pugh grade ${ }^{[61,64,69]}$. Most of the studies have shown that before liver resection or transplantation, tumor cells from the primary lesions were detached and threw into the blood being the early event of HCC metastases. Fan et al ${ }^{[69,70]}$ reported that the tumor recurrence after resection was associated with the number of CTCs detected, maybe because CTCs were still surviving into the blood ${ }^{[70-72]}$. However, the role of CTCs and HCC recurrence require further investigations. The enumeration and characterization of CTCs may become an indispensable biomarker for monitoring the efficacy of HCC treatments however, clinical application of CTC assay in HCC remains in the initial stage, especially in the field of early diagnosis.

\section{Cell-free tumor associated DNA}

Circulating cell-free DNA (cfDNA) is defined as extracellular DNA present in plasma or serum samples. cfDNA is released into circulation from cells that undergo metabolic secretion, apoptosis or necrosis. Cells are phagocytized by macrophages releasing digested DNA into the circulating system. Tumor cells are considered to be the major source of tumor-related cfDNA in blood of cancer patients ${ }^{[73,74]}$. cfDNA is also detected in healthy patients but in patients suffering from cancer cfDNA carries tumor-specific genetic or epigenetic alterations, such as mutations, copy number variations, chromosomal rearrangements or DNA methylations among others ${ }^{[54]}$. Compared to tissue biopsy, circulating tumor DNA (ctDNA) may represent the entire molecular biology of the tumor and its qualitative and quantitative analysis might help to assess the biological characteristics of the tumor. Recently, several studies have demonstrated that ctDNA could be a non-invasive potential biomarker ${ }^{[54,75]}$. ctDNA is highly specific and could be detected easier compared to CTCs purification, thus it could be an ideal source for the early diagnosis or as recurrence biomarker ${ }^{[76,77]}$.

To study the ctDNA in plasma or serum two strategies are implemented: (a) measuring the quantity or (b) detecting tumor - specific genetic aberrations.

Several studies have shown that HCC patients have large amounts of cfDNA being these associated with the degree of malignancy (poorer prognosis) and size of the tumor size ${ }^{[77,78]}$. Huang et al ${ }^{[77]}$ showed that plasma DNA detection was able to discriminate HCC from normal controls with $90.2 \%$ sensitivity and $90.3 \%$ specificity and AUC was 0.949 (95\% CI) (measured by real-time quantitative PCR method). Moreover, plasma DNA and serum AFP revealed an elevated AUC of 0.974 with $95.1 \%$ sensitivity and $94.4 \%$ specificity in discriminating HCC from normal controls. Furthermore, the plasma DNA levels were positively associated with tumor size and vascular invasion $(P=0.012 \text { and } P=0.035 \text { respectively })^{[77]}$. However further studies are needed due to the controversial results related to the methodology used.

Changes of DNA mutations could play an important role in the carcinogenesis process ${ }^{[79-82]}$. By now, several studies confirmed that TP53, EFGR, KRAS and APC are genes with common tumor specific mutations. The proportion of HCC patients with detectable ctDNA varies wildly between studies. Tumor suppressive gene TP53 mutations such as Ser249, were found present in 50\% of HCC patients exposed to aflatoxin ${ }^{[83]}$. However, Ser249 of TP53, one of the most reported mutations in HCC patients, was also detected in non- 
cancer liver tissue of HCC, in plasma from healthy people, indicating that this mutation is not exclusive of HCC $^{[84,85]}$. In addition, rs894151 or rs12428080 were found significantly associated with a decreased overall survival and time to recurrence after liver transplantation ${ }^{[86,87]}$. Using digital droplet PCR, ctDNA mutations in TERT promoter, CTNNB1 and TP53 could be detected in a higher rate (56\%) compared to the use of NGS (20\%). A recent pilot study of ultra-deep targeted sequencing of plasma DNA identifies driver mutations and it demonstrates how ultra- deep targeted sequencing of cfDNA in the plasma of HCC patients is a feasible, reliable and minimally invasive approach to interrogate HCC genetics and emerges as a promising tool for predictive biomarker development in $\mathrm{HCC}^{[88]}$.

DNA methylation is also an important epigenetic aberration found in ctDNA with a great application in the diagnosis, prognosis, and effective evaluation of HCC. Another tumor suppressor gene, Ras association domain family protein 1A (RASSF1A) was found hypermethylated in 93\% HCC patients compared to healthy people being this frequency similar to the one found in RASSF1A hypermethylation in HCC tumor tissues $^{[89]}$. Moreover, the combination of several methylations has been postulated in order to improve the specificity and efficacy for the early diagnosis ${ }^{[90]}$. The plasma methylation levels of APC, GSTP1, RASSF1A, and SFRP1 were significantly higher in HCCs than those in normal or benign controls $(P<0.05)$. The combination of these four genes resulted in an increased AUC of 0.933 with $92.7 \%$ sensitivity and $81.9 \%$ specificity in discriminating HCC from normal control and GSTP1 hypermethylation was significantly correlated with elevated serum AFP levels $(P=0.026)$.

Finally, the clinical significance of ctDNA as a diagnostic and predictive biomarker in HCC patients should be further evaluated. ctDNA may be quite low and therefore below the limit of detection, especially in earlystage and indolent tumors. The improvement of different technics such as digital PCR and sequencing technologies provide us an effective way for the discovery of additional ctDNA markers ${ }^{[1,92]}$.

\section{Circulating non-coding RNA}

In the context of liquid biopsy, non-coding RNA (ncRNA) is also included. The number of ncRNA genes is increasing due to the development of high-throughput RNA sequencing technology. They have a role in several physiological and pathological processes such as cancer. The main feature is their lack to codify for proteins. Depending on the length, ncRNAs could be classified into short or long ncRNAs with an arbitrary size cut-off at 200 bases of length, being the most known (a) the long-ncRNA (lncRNA) and (b) the microRNA (miRNA).

lncRNAs function take place by different molecular mechanisms such as interactions with DNA, RNA and proteins and can be classified into oncogenic or tumor suppressive genes ${ }^{[93-98]}$. Besides lncRNAs, miRNAs are endogenous small RNAs molecules with 20-25 bases of length. They are involved in multiple activities of mammalian cells like lncRNA but its function is to regulate gene expression through their binding to the $3^{\prime}$ UTR of mRNAs and consequently degradation or translational suppression of targeted gene transcript ${ }^{[99]}$. Both lncRNAs and miRNAs are often deregulated in liver cancer and it has been reported the existence of circulating particle shape ncRNA in the peripheral blood. A group of ncRNA is packaged into small membrane vesicles called exosomes, binding to lipoprotein or other proteins in order to increase its stability $^{[100-103]}$. In fact, the possibility that circulating ncRNA could be useful as a biomarker in the context of HCC is raising. Interestingly, modified circulating levels of these RNAs were repeatedly found in HCC patients.

\section{Circulating $\ln c R N A s$}

lncRNAs have emerged as important regulators of gene expression in many types of cancer including $\mathrm{HCC}^{[104,105]}$. Alterations in expression of several lncRNAs have been recently reported in HCC.

Serum levels of lncRNA-uc003wbd and lncRNA-AF085935 were found upregulated in HCC and HBV 
patients compared to controls, showing that both lncRNAs could be potential biomarkers for HCC and HBV screening $(P<0.001)$. HCC patients compared with normal group showed an AUC value for lncRNAuc003wbd: 0.86 (95\% CI: 0.82-0.91) and for IncRNA-AF085935 was 0.96 (95\% CI: 0.93-0.99). Authors suggest that both $\operatorname{lncRNAs}$ may serve as potential biomarkers for the detection of HCC and $\mathrm{HBV}^{[106]}$. Long intergenic non-protein coding RNA 974 (Linc00974F-1) was increased in serum of HCC patients and it was useful as a tumor marker to improve the prognosis of HCC. The combination of Linc00974F-1 and CYFRA21-1 showed an AUC: 0.866 , indicating a significant predictor of tumor growth and metastasis ${ }^{[107]}$. In addition, SPRY4-IT1 expression was upregulated in the plasma from HCC patients suggesting this one to be a good diagnostic biomarker. Combination of SPRY4-IT1 and AFP (the cut-off value of AFP was at $200 \mathrm{ng} / \mathrm{mL}$ ) possessed a moderate ability for discrimination between HCC patients and controls; the area was equal to $0.80^{[108]}$. Highly upregulated in liver cancer (HULC) lncRNA has been implicated in the regulation of hepatoma cell proliferation, since it induces HCC cells to activate EMT and then promotes tumor progression and metastasis through the miR-200a/ZEB1 signalling pathway ${ }^{[109]}$. Furthermore, HULC IncRNA was upregulated in the plasma of HCC patients compared to healthy controls (HULC was detected in 63\% (19/30) of the HCC patients and 10\% in the healthy control group (2/20) and with a positive correlation to Edmondson grades (the detection rates were 14\%, 62\%, and 100\% for Edmondson grades I-II, II-III, and IIIIV, respectively ${ }^{[110]}$. The lncRNA DANCR activates the Wnt pathway, one of the most important pathways responsible of HCC development ${ }^{[111]}$. DANCR was up-regulated in tumor tissues and plasma of patients with HCC, and its expression was highly correlated with microvascular and liver capsule invasion of HCC. The results showed that AUC for plasma DANCR was 0.868 which was higher than that for AFP (AUC = 0.744) when differentiating patients with HCC from non-HCC patients ${ }^{[12]}$. Besides these circulating lncRNAs, JPX, UCA1 and WRAP53 were found increased in HCC patients ${ }^{[106,113,114]}$ alone or in combination with other lncRNAs, miRNAs or serum biomarkers ${ }^{[115]}$. Many reports have indicated that the deregulation of lncRNAs plays important roles in occurrence and progression of HCC however further studies are needed in order to use these as biomarkers.

\section{Circulating miRNAs}

Numerous studies have shown that circulating miRNAs are closely associated with tumor development and progression. In spite of these findings, miRNAs are considered good biomarkers for differentiating between HCC and healthy people.

For instance, miR-122 is a liver-specific miRNA whose role is to maintain the liver homeostasis. The loss of its expression contributes to the malignant phenotype of HCC cells and it has been described as the miRNA responsible to develop HCC in HCV infection ${ }^{[116]}$. However, controversial results about miR122 were reported due to the underlying aetiology and active ongoing necroinflammatory changes. miR122 was found significantly downregulated in HBV-related $\mathrm{HCC}^{[117]}$ and Xu et al ${ }^{[118]}$ found it increased in serum from patients with HCC and chronic hepatitis B together with miR-21 and miR-223. A positive linear correlation was present between serum ALT and serum miR-122 levels in mouse models of alcoholic liver disease $(r=0.893 ; P<0.001)^{[100]}$ and it was postulated to be a key regulator of alpha-fetoprotein expression and it could influence the aggressiveness of the HCC in an in vitro model ${ }^{[119]}$. Using panels of miRNAs may provide a high diagnostic accuracy of HCC regardless of the disease status, and it can also differentiate HCC from healthy controls and chronic liver injury ${ }^{[120,121]}$. These were hsa-miR-206, hsa-miR-141-3p, hsamiR-433-3p, hsa-miR-1228-5p, hsa-miR-199a-5p, hsa-miR-122-5p, hsa-miR-192-5p, and hsa-miR-26a-5p. The diagnostic accuracy using these miRNAs, as measured by AUC, was 0.665, 0.68, 0.607, 0.534, 0.609, 0.729, 0.69 and 0.677 , respectively ${ }^{[120]}$. Ali et al. ${ }^{[121]}$ showed that miR-122, miR-21 and miR-222 had the highest sensitivity and specificity, in discriminating HCC from healthy controls (miR-122: 94.3\% and 92.9\% respectively; miR21: $80 \%$ and $92.9 \%$ respectively, and miR-222: $82.9 \%$ and $78.6 \%$, respectively).

Another study demonstrated that serum miR-122, miR-885-5p, miR-221, miR-22 in association with AFP showed a high diagnostic accuracy for early detection of HCC in a cohort of cirrhotic patients (AUC $=0.982$ ), 
in the meantime that miR-122, miR-885-5p and miR-29b in association with AFP showed a high diagnostic accuracy for early detection of HCC in general population $(\mathrm{AUC}=1)^{[122]}$. The combination of lncRNA and miRNAs has been also studied. IncRNA-CTBP, miR-16-2, miR-21-5p and LAMP2 had high sensitivities (91\%, 92.3\%, 93.6\% and 92.3\% respectively) for discriminating HCC from healthy subjects and also from chronic hepatitis C patients $(75 \%, 88.9 \%, 88.9 \% \text { and } 94.9 \% \text { respectively })^{[123]}$. miR-224 was highly expressed in HCC tissue and plasma, and after surgery the levels were normalized suggesting that miR-224 could reflect tumor dynamisms. There was an association between plasma miR-224 level, tumor size $(P=0.0005)$ and the incidence of recurrence $(P=0.0027)$. However no significant correlation were found with AFP serum levels ${ }^{[124]}$.

In addition, miR-21 was found upregulated in plasma from HCC patients compared to healthy volunteers. The combination of miR-21 and AFP increased its diagnostic value (more than 90\%) suggesting its potential use as a biomarker of HCC diagnosis ${ }^{[125]}$. A systematic review and meta-analysis concluded that circulating miRNAs, particularly miR-21 and miR-122 are promising biomarkers for the early diagnosis of HCC ${ }^{[126]}$. In addition, miR-21 (oncogene) and miR-182 (tumor suppressor gene) were related with the development of $\operatorname{metastasis}^{[127,128]}$.

Due to the diversity showed in the results, numerous profiling studies are ongoing in order to report miRNA profiles based on sequencing microarrays to examine circulating miRNAs as HCC-associated biomarkers.

\section{Tumor-associated circulating microparticles}

Large cells membrane-derived extracellular vesicles (EVs), known as microparticles (MPs) and microvesicles $(\mathrm{MVs})$, have been reported to play a role in the horizontal communication between cells ${ }^{[129]}$.

Hepatocytes secrete exosomes, MPs and MVs, and their production can change quantitatively and qualitatively in response to cellular stimulation and under different disease condition ${ }^{[130]}$. It was shown that tumors prepare their own tumor niches via the release of EVs including a possible suppression of the immune system and the activation of tumor neo-angiogenesis ${ }^{[131]}$. MPs are between 100 and $1000 \mathrm{~nm}$ in size and bear on their surface the antigenic markers of the parent cell. They are formed and released during cellular activation or in early stages of apoptosis into the extracellular space. MPs can be isolated from whole blood, plasma and serum ${ }^{[132]}$.

Proteomic analysis revealed the presence of $\sim 251$ proteins in EVs derived from primary rat hepatocytes ${ }^{[133]}$. Something that we have to be in account is that exosomes do not carry cell surface markers of their origin cells however MPs carry the surface signature of their cell of origin and the quantification of MP subsets using FACS sorting allows a non-invasive assessment of cell specific pathologies. Nowadays, there are many studies which focus is to identify the most efficient surface markers of tumor associated MPs (taMPs) and liver disease ${ }^{[134-136]}$.

A recent study showed that EpCAM and CD147 double positive taMPs could be a biomarker to compare colorectal carcinoma (CRC), non-small cell lung carcinoma (NSCLC) and pancreas carcinoma with healthy subjects. In all three types of tumor entities, EmCAM+CD147+ taMPs were found increased (AUROC: $0.8597,0.8700$ and 0.9000 respectively) indicating cancer presence. In addition, EpCAM+CD147+ taMPs were significantly correlating with CRC tumor volume $(r=0.7288, P<0.0001)$. Furthermore, EpCAM+ taMPs were found decreased after tumor resection in serum of CRC patients suggesting a close dependence with tumor presence ${ }^{[134]}$. They conclude that EpCAM+ and EpCAM+CD147+ taMPs might serve as an early indicator of cancer growth and monitor successful anti-tumour therapy and might be used as important liquid biopsy tool to differentiate between therapy responders and non-responders ${ }^{[134]}$.

Regarding HCC the role of circulating MPs as potential biomarkers is under intensive investigation. Abbate and colleagues showed that HepPar1-MPs are increased in the blood of subjects with HCC compared to 
subjects with only liver cirrhosis or healthy livers $(P<0.01)$. An additional interesting finding of this study was the association between HepPar1+ MPs and the early recurrence of HCC after liver resection. HepPar1+ MPs, measured before liver resection, were significantly more numerous in the blood of subjects which displayed recurrence $(P=0.021)^{[135]}$.

Additionally, other study reported that MPs profiling for distinct MPs populations that are associated with chronic liver diseases robustly discriminates between chronic HCV infection and non-alcoholic fatty liver disease ${ }^{[136]}$. Julich-Haertel et al. ${ }^{[137]}$ successfully differentiated HCC and cholangiocarcinoma (CCA) from chronic diseases without liver tumours base on MPs profile. AnnexinV+ EpCAM+ CD147+ taMPs were increased in HCC and CCA. Moreover, AnnexinV+ EpCAM+ ASGPR1+ taMPs allowed to differentiate between liver cancer (HCC or CCA) and cirrhosis from tumour-free individuals (sensitivity $75 \%$ and specificity $47 \%)^{[137]}$. AnnexinV+ EpCAM+ ASGPR1+ taMPs were increased in liver cancer and decreased after liver resection indicating the powerful diagnostic accuracy $(P<0.05)$ and these MPs were correlated "moderately" with liver tumos diameters $(r=0.56, P>0.001)$. However, no significant correlation between AFP levels, tumour diameter and AnnexinV+ EpCAM+ ASGPR1+ taMPs was found ${ }^{[137]}$.

The evidence about the hypothesis that taMPs populations could be used as a novel liquid biopsy tool to identify and discriminate liver tumours in patients with cirrhosis and their use as diagnostic and responder biomarkers need further studies.

\section{CONCLUSIONS}

In conclusion, nowadays the early diagnosis of HCC is difficult, despite being of vital importance for an adequate treatment and the consequent improvement of survival in these patients. However, no single biomarker represents an optimum sensitive and specific tool for this purpose.

Therefore, a study has been recently published in which several biomarkers (AFP, AFP-L3 and DCP) were combined to validate two statistical models for the early diagnosis and prognosis of HCC (GALAD and BALAD-2, respectively). Thus, GALAD discriminated patients with HCC from those with other hepatobiliary cancers with an area under the ROC curve (AUROC) value of 0.95, lower in case of small unifocal HCC (0.85-0.95). On the other hand, BALAD-2 established 4 different groups depending on the prognosis ${ }^{[138]}$. In addition, there are many other biomarkers that are under study to check their utility in the management of this disease, such as golgi protein-73, osteopontin, soluble urokinase plasminogen receptor activator, etc.

The utility of the current blood molecular biomarkers included in the context of liquid biopsy, are promising as diagnostic, therapeutic and/or prognostic markers for HCC. Regarding this, a liquid biopsy could give us information about the genetics and epigenetics alterations present in the tumor showing great advantages compared to tissue biopsies; it is a non-invasive method to determine the molecular biology of the tumor as well as the feasibility of taking samples in order to monitorize the tumor state in real time. However, due to the lack of standardized technical approach, data is quite different among various studies. With the standardization of effective methods, liquid biopsy biomarkers alone or in combination with conventional serum biomarkers might serve as promising diagnostic, prognostic, therapeutic monitoring and risk assessment of HCC.

\section{DECLARATIONS}

\section{Authors' contributions}

Substantial contributions to the conception, the acquisition, analysis, and interpretation of data: Rojas Á, Sánchez-Torrijos Y, Gil-Gómez A, Liu CH, Rodríguez-Rivas C 
Conception and design of the work: Rojas Á, Romero-Gómez M

Final approval of the version to be published: Ferrer MT, Romero-Gómez M

\section{Availability of data and materials}

Not applicable.

\section{Financial support and sponsorship}

The National Institutes of Health, Institute of Health Carlos III, ISCIII (PI16/01842 to Dr. Romero-Gómez); The Andalusian Health Service - Junta de Andalucía (PC-033-2017 to Dra. Rojas).

\section{Conflicts of interest}

All authors declare that there are no conflicts of interest.

\section{Ethical approval and consent to participate}

Not applicable.

\section{Consent for publication}

Not applicable.

\section{Copyright}

(c) The Author(s) 2018.

\section{REFERENCES}

1. World Health Organization. Globocan 2012: Estimated Cancer Incidence, Mortality and Prevalence Worldwide in 2012. Available from: http://globocan.iarc.fr/Default.aspx [Last accessed on 27 Jun 2018].

2. Malvezzi M, Bertuccio P, Levi F, La Vecchia C, Negri E. European cancer mortality predictions for the year 2012. Ann Oncol 2012;23:104452.

3. Ronot M, Bouattour M, Wassermann J, Bruno O, Dreyer C, Larroque B, Castera L, Vilgrain V, Belghiti J, Raymond E, Faivre S. Alternative Response Criteria (Choi, European Association for the Study of the Liver, and Modified Response Evaluation Criteria in Solid Tumors [RECIST]) versus RECIST 1.1 in patients with advanced hepatocellular carcinoma treated with sorafenib. Oncologist 2014;19:394-402.

4. Sterling RK, Jeffers L, Gordon F, Venook AP, Reddy KR, Satomura S, Kanke F, Schwartz ME, Sherman M. Utility of lens culinaris agglutinin-reactive fraction of $\alpha$-fetoprotein and des-gamma-carboxy prothrombin, alone or in combination, as biomarkers for hepatocellular carcinoma. Clin Gastroenterol Hepatol 2009;7:104-13.

5. Debruyne EN, Delanghe JR. Diagnosing and monitoring hepatocellular carcinoma with alpha-fetoprotein: new aspects and applications. Clin Chim Acta 2008;395:19-26.

6. Zhang BH, Yang BH, Tang ZY. Randomized controlled trial of screening for hepatocellular carcinoma. J Cancer Res Clin Oncol 2004;130:417-22.

7. Chayvialle JAP, Ganguli PC. Radioimmunoassay of alpha-fetoprotein in human plasma. Lancet 1973;301:1355-7.

8. Lok AS, Sterling RK, Everhart JE, Wright EC, Hoefs JC, Di Bisceglie AM, Morgan TR, Kim HY, Lee WM, Bonkovsky HL, Dienstag JL. Des- $\gamma$-carboxy prothrombin and $\alpha$-fetoprotein as biomarkers for the early detection of hepatocellular carcinoma. Gastroenterology 2010;138:493-502.

9. Marrero JA, Feng Z, Wang Y, Nguyen MH, Befeler AS, Roberts LR, Reddy KR, Harnois D, Llovet JM, Normolle D, Dalhgren J, Chia D, Lok AS, Wagner PD, Srivastava S, Schwartz M. $\alpha$-fetoprotein, des- $\gamma$ carboxyprothrombin, and lectin-bound $\alpha$-fetoprotein in early hepatocellular carcinoma. Gastroenterology 2009;137:110-8.

10. Heimbach JK, Kulik LM, Finn RS, Sirlin CB, Abecassis MM, Roberts LR, Zhu AX, Murad MH, Marrero JA. AASLD guidelines for the treatment of hepatocellular carcinoma. Hepatology 2018;67:358-80.

11. Llovet JM, Ducreux M, Lencioni R, Di Bisceglie AM, Galle PR, Dufour JF, Greten TF, Raymond E, Roskams T, De Baere T, Ducreux M, Mazzaferro V, Bernardi M, Bruix J, Colombo M, Zhu A. EASL-EORTC clinical practice guidelines: management of hepatocellular carcinoma. J Hepatol 2012;56:908-43.

12. Singal AG, Pillai A, Tiro J. Early detection, curative treatment, and survival rates for hepatocellular carcinoma surveillance in patients with cirrhosis: a meta-analysis. PLoS Med 2014;11:e1001624.

13. She WH, Chan ACY, Cheung TT, Lo CM, Chok KSH. Survival outcomes of liver transplantation for hepatocellular carcinoma in patients with normal, high and very high preoperative alpha-fetoprotein levels. World J Hepatol 2018;10:308-18.

14. Toyoda H, Kumada T, Kiriyama S, Sone Y, Tanikawa M, Hisanaga Y, Hayashi K, Honda T, Kitabatake S, Kuzuya T, Nonogaki K, Kasugai T, Shimizu J. Changes in the characteristics and survival rate of hepatocellular carcinoma from 1976 to 2000: analysis of 1365 patients in a single institution in Japan. Cancer 2004;100:2415-21.

15. Tsuchiya N, Sawada Y, Endo I, Saito K, Uemura Y, Nakatsura T. Biomarkers for the early diagnosis of hepatocellular carcinoma. World J Gastroenterol 2015;21:10573-83. 
16. Spangenberg HC, Thimme R, Blum HE. Serum markers of hepatocellular carcinoma. Semin Liver Dis 2006;26:385-90.

17. Li D, Mallory T, Satomura S. AFP-L3: a new generation of tumor marker for hepatocellular carcinoma. Clin Chim Acta 2001;313:15-9.

18. Abdel-Aziz MM, Elshal MF, Abass AT, El-Kafrawy S, Ezzat S, Abdel-Wahab M. Comparison of AFP-L3 and p53 antigen concentration with alpha-fetoprotein as serum markers for hepatocellular carcinoma. Clin Lab 2016;62:1121-9.

19. Oda K, Ido A, Tamai T, Matsushita M, Kumagai K, Mawatari SI, Saishoji A, Kure T, Ohno K, Toyokura E, Imanaka D, Moriuchi A, Uto H, Oketani M, Hashiguchi T, Tsubouchi H. Highly sensitive lens culinaris agglutinin-reactive $\alpha$-fetoprotein is useful for early detection of hepatocellular carcinoma in patients with chronic liver disease. Oncol Rep 2011;26:1227-33.

20. Yi X, Yu S, Bao Y. Alpha-fetoprotein-L3 in hepatocellular carcinoma: a meta-analysis. Clin Chim Acta 2013;425:212-20.

21. Bertino G, Ardiri AM, Boemi PM, Ierna D, Interlandi D, Caruso L, Minona E, Trovato MA, Vicari S, Li Destri G, Puleo S. A study about mechanisms of des-gamma-carboxy prothrombin's production in hepatocellular carcinoma. Panminerva Med 2008;50:221-6.

22. Okuda H, Nakanishi T, Takatsu K, Saito A, Hayashi N, Yamamoto M, Takasaki K, Nakano M. Comparison of clinicopathological features of patients with hepatocellular carcinoma seropositive for $\alpha$-fetoprotein alone and those seropositive for des- $\gamma$-carboxy prothrombin alone. Gastroenterol Hepatol 2001;16:1290-6.

23. Hong YM, Cho M, Yoon KT, Chu CW, Yang KH, Park YM, Rhu JH. Risk factors of early recurrence after curative hepatectomy in hepatocellular carcinoma. Tumor Biol 2017;39:1-9.

24. Hamamura K, Shiratori Y, Shiina S, Imamura M, Obi S, Sato S, Yoshida H, Omata M. Unique clinical characteristics of patients with hepatocellular carcinoma who present with high plasma des-gamma-carboxy prothrombin and low serum alpha-fetoprotein. Cancer 2000;88:1557-64.

25. Bertino G, Ardiri AM, Calvagno GS, Bertino N, Boemi PM. Prognostic and diagnostic value of des- $\gamma$-carboxy prothrombin in liver cancer. Drug News Perspect 2010;23:498-508.

26. Suehiro T, Matsumata T, Itasaka H, Taketomi A, Yamamoto K, Sugimachi K. Des-gamma-carboxy prothrombin and proliferative activity of hepatocellular carcinoma. Surgery 1995;117:682-91.

27. Sung YK, Hwang SY, Park MK, Farooq M, Han IS, Bae HI, Kim JC, Kim M. Glypican-3 is overexpressed in human hepatocellular carcinoma. Cancer Sci 2003;94:259-62.

28. Liu XF, Hu Z De, Liu XC, Cao Y, Ding CM, Hu CJ. Diagnostic accuracy of serum glypican-3 for hepatocellular carcinoma: a systematic review and meta-analysis. Clin Biochem 2014;47:196-200.

29. Tahon AM, El-Ghanam MZ, Zaky S, Emran TM, Bersy AM, El-Raey F, AZ E, El Kharsawy AM, Johar D. Significance of glypican-3 in early detection of hepatocellular carcinoma in cirrhotic patients. J Gastrointest Cancer 2018; doi: 10.1007/s12029-018-0095-2.

30. El-Saadany S, El-Demerdash T, Helmy A, Mayah WW, El-Sayed Hussein B, Hassanien M, Elmashad N, Fouad MA, Basha EA. Diagnostic value of glypican-3 for hepatocellular carcinomas. Asian Pac J Cancer Prev 2018;19:811-7.

31. Libbrecht L, Severi T, Cassiman D, Borght S Vander, Pirenne J, Nevens F, Verslype C, ven Pelt J, Roskams T. Glypican-3 expression distinguishes small hepatocellular carcinomas from cirrhosis, dysplastic nodules, and focal nodular hyperplasia-like nodules. Am J Surg Pathol 2006;30:1405-11.

32. Capurro MI, Xiang YY, Lobe C, Filmus J. Glypican-3 promotes the growth of hepatocellular carcinoma by stimulating canonical Wnt signaling. Cancer Res 2005;65:6245-54.

33. Filmus J, Capurro M. Glypican-3: a marker and a therapeutic target in hepatocellular carcinoma. FEBS J 2013;280:2471-6.

34. Abou-Alfa GK, Yen CJ, Hsu CH, O’Donoghue J, Beylergil V, Ruan S, Pandit-Taskar N, Gansukh B, Lyashchenko SK, Ma J, Wan P, Shao YY, Lin ZZ, Frenette C, O’Neil B, Schwartz L, Smith-Jones PM, Ohtomo T, Tanaka T, Morikawa H, Maki Y, Ohishi N, Chen YC, Agajano CJ. Phase Ib study of codrituzumab in combination with sorafenib in patients with non-curable advanced hepatocellular carcinoma (HCC). Cancer Chemother Pharmacol 2017;79:421-9.

35. Ikeda M, Ohkawa S, Okusaka T, Mitsunaga S, Kobayashi S, Morizane C, Suzuki I, Yamamoto S, Furuse J. Japanese phase I study of GC33, a humanized antibody against glypican-3 for advanced hepatocellular carcinoma. Cancer Sci 2014;105:455-62.

36. Abou-Alfa GK, Puig O, Daniele B, Kudo M, Merle P, Park JW, Ross P, Peron JM, Ebert O, Chan S, Poon TP, Colombo M, Okusaka T, Ryoo BY, Minguez B, Tanaka T, Ohtomo T, Ukrainskyj S, Boisserie F, Rutman O, Chen YC, Xu C, Shochat E, Jukofsky L, Reis B, Chen G, Di Laurenzio L, Lee R, Yen CJ. Randomized phase II placebo controlled study of codrituzumab in previously treated patients with advanced hepatocellular carcinoma. J Hepatol 2016;65:289-95.

37. Wu Q, Pi L, Le Trinh T, Zuo C, Xia M, Jiao Y, Hou Z, Jo S, Puszyk W, Pham K, Nelson DR, Robertson K, Ostrov D, Rameshwar P, Xia CQ, Liu C. A novel vaccine targeting glypican-3 as a treatment for hepatocellular carcinoma. Mol Ther 2017;25:2299-308.

38. Sawada Y, Yoshikawa T, Nobuoka D, Shirakawa H, Kuronuma T, Motomura Y, Mizuno S, Ishii H, Nakachi K, Konishi M, Nakagohri T, Takahashi S, Gotohda N, Takayama T, Yamao K, Uesaka K, Furuse J, Kinoshita T, Nakatsura T. Phase I trial of a glypican-3-derived peptide vaccine for advanced hepatocellular carcinoma: immunologic evidence and potential for improving overall survival. Clin Cancer Res 2012;18:3686-96.

39. Tsuchiya N, Yoshikawa T, Fujinami N, Saito K, Mizuno S, Sawada Y, Endo I, Nakatsura T. Immunological efficacy of glypican-3 peptide vaccine in patients with advanced hepatocellular carcinoma. Oncoimmunology 2017;6:e1346764.

40. Sun Y, Sheshadri N, Zong WX. SERPINB3 and B4: from biochemistry to biology. Semin Cell Dev Biol 2017;62:170-7.

41. Pontisso P, Calabrese F, Benvegnù L, Lise M, Belluco C, Ruvoletto MG, De Falco S, Marino M, Valente M, Nitti D, Gatta A, Fassina G. Overexpression of squamous cell carcinoma antigen variants in hepatocellular carcinoma. Br J Cancer 2004;90:833-7.

42. Turato C, Cannito S, Simonato D, Villano G, Morello E, Terrin L, Quarta S, Biasiolo A, Ruvoletto M, Martini A, Fasolato S, Zanus G, Cillo U, Gatta A, Parola M, Pontisso P. SerpinB3 and Yap interplay increases Myc oncogenic activity. Sci Rep 2015;5:17701.

43. Pontisso P. Role of SERPINB3 in hepatocellular carcinoma. Ann Hepatol 2014;13:722-7.

44. Biasiolo A, Trotta E, Fasolato S, Ruvoletto M, Martini A, Gallotta A, Fassina G, Angeli P, Gatta A, Pontisso P. Squamous cell carcinoma antigen-IgM is associated with hepatocellular carcinoma in patients with cirrhosis: a prospective study. Dig Liver Dis 2016;48:197-202.

45. Suminami Y, Nagashima S, Murakami A, Nawata S, Gondo T, Hirakawa H, Numa F, Silverman GA, Kato H. Suppression of a squamous cell carcinoma (scc)-related serpin, scc antigen, inhibits tumor growth with increased intratumor infiltration of natural killer cells. Cancer 
Res 2001;61:1776-80.

46. Martini A, Gallotta A, Pontisso P, Fassina G. Clinical applications of squamous cell carcinoma antigen-immunoglobulins M to monitor chronic hepatitis C. World J Hepatol 2015;7:2913-9.

47. Novo E, Villano G, Turato C, Cannito S, Paternostro C, Busletta C, Biasiolo A, Quarta S, Morello E, Bocca C, Miglietta A, David E, Sutti S, Plebani M, Albano E, Parola M, Pontisso P. SerpinB3 promotes pro-fibrogenic responses in activated hepatic stellate cells. Sci Rep 2017:7:3420.

48. Pozzan C, Cardin R, Piciocchi M, Cazzagon N, Maddalo G, Vanin V, Giacomin A, Pontisso P, Cillo U, Farinati F. Diagnostic and prognostic role of SCCA-IgM serum levels in hepatocellular carcinoma (HCC). J Gastroenterol Hepatol 2014;29:1637-44.

49. Heitzer E, Perakis S, Geigl JB, Speicher MR. The potential of liquid biopsies for the early detection of cancer. NPJ Precis Oncol 2017;1:36.

50. Crowley E, Di Nicolantonio F, Loupakis F, Bardelli A. Liquid biopsy: monitoring cancer-genetics in the blood. Nat Rev Clin Oncol 2013;10:472-84.

51. Bardelli A, Pantel K. Liquid biopsies, what we do not know (yet). Cancer Cell 2017;31:172-9.

52. Alix-Panabières C, Pantel K. Clinical applications of circulating tumor cells and circulating tumor DNA as liquid biopsy. Cancer Discov 2016;6:479-91

53. Okajima W, Komatsu S, Ichikawa D, Miyamae M, Ohashi T, Imamura T, Kiuchi J, Nishibeppu K, Arita T, Konishi H, Shiozaki A, Morimura R, Ikoma H, Okamoto K, Otsuji E. Liquid biopsy in patients with hepatocellular carcinoma: circulating tumor cells and cell-free nucleic acids. World J Gastroenterol 2017;23:5650-68.

54. Yin CQ, Yuan CH, Qu Z, Guan Q, Chen H, Wang FB. Liquid biopsy of hepatocellular carcinoma: circulating tumor-derived biomarkers. Dis Markers 2016;2016:1427849.

55. Zhou J, Huang A, Yang XR. Liquid biopsy and its potential for management of hepatocellular carcinoma. J Gastrointest Cancer 2016;47:157-67.

56. Labgaa I, Villanueva A. Liquid biopsy in liver cancer. Discov Med 2015;105:263-73.

57. Chaffer CL, Weinberg RA. A perspective on cancer cell metastasis. Science 2011;331:1559-64.

58. Jiang Y, Wang D. Liquid biopsy in the OMICS era of tumor medicine. Open Access J Biomed Eng Appl 2018;1:115

59. Ashworth T. A case of cancer in which cells similar to those in the tumours were seen in the blood after death. Aust Med J 1869;14:146-9.

60. Miller MC, Doyle GV, Terstappen LW. Significance of circulating tumor cells detected by the CellSearch system in patients with metastatic breast colorectal and prostate cancer. J Oncol 2010;2010:1-8.

61. Vona G, Estepa L, Béroud C, Damotte D, Capron F, Nalpas B, Mineur A, Franco D, Lacour B, Pol S, Bréchot C, Paterlini-Bréchot P. Impact of cytomorphological detection of circulating tumor cells in patients with liver cancer. Hepatology 2004;39:792-7.

62. Krebs MG, Metcalf RL, Carter L, Brady G, Blackhall FH, Dive C. Molecular analysis of circulating tumour cells - biology and biomarkers Nat Rev Clin Oncol 2014;11:129-44.

63. Wu LJ, Pan Y Da, Pei XY, Chen H, Nguyen S, Kashyap A, Liu J, Wu J. Capturing circulating tumor cells of hepatocellular carcinoma. Cancer Lett 2012;326:17-22.

64. Thompson EW, Haviv I. The social aspects of EMT-MET plasticity. Nat Med 2011;17:1048-9

65. Guo W, Yang XR, Sun YF, Shen MN, Ma XL, Wu J, Zhang CY, Zhou Y, Xu Y, Hu B, Zhang X, Zhou J, Fan J. Clinical significance of EpCAM mRNA-positive circulating tumor cells in hepatocellular carcinoma by an optimized negative enrichment and qRT-PCR-based platform. Clin Cancer Res 2014;20:4794-805.

66. Nagrath S, Sequist L V., Maheswaran S, Bell DW, Irimia D, Ulkus L, Smith MR, Kwak EL, Digumarthy S, Muzikansky A, Ryan P, Balis UJ, Tompkins RG, Haber DA, Toner M. Isolation of rare circulating tumour cells in cancer patients by microchip technology. Nature. 2007:450:1235-9.

67. Xu W, Cao L, Chen L, Li J, Zhang XF, Qian HH, Kang XY, Zhang Y, Liao J, Shi LH, Yang YF, Wu MC, Yin ZF. Isolation of circulating tumor cells in patients with hepatocellular carcinoma using a novel cell separation strategy. Clin Cancer Res 2011;17:3783-93.

68. Olthoff KM, Forner A, Hübscher S, Fung J. What is the best staging system for hepatocellular carcinoma in the setting of liver transplantation? Liver Transpl 2011;17 Suppl 2:S26-33.

69. Fan JL, Yang YF, Yuan CH, Chen H, Wang FB. Circulating tumor cells for predicting the prognostic of patients with hepatocellular carcinoma: a meta analysis. Cell Physiol Biochem 2015;37:629-40.

70. Fan ST, Yang ZF, Ho DWY, Ng MNP, Yu WC, Wong J. Prediction of posthepatectomy recurrence of hepatocellular carcinoma by circulating cancer stem cells: a prospective study. Ann Surg 2011;254:569-76.

71. Kim MY, Oskarsson T, Acharyya S, Nguyen DX, Zhang XHF, Norton L, Massagué J. Tumor self-seeding by circulating cancer cells. Cell 2009;139:1315-26

72. Pantel K, Brakenhoff RH, Brandt B. Detection, clinical relevance and specific biological properties of disseminating tumour cells. Nat Rev Cancer 2008;8:329-40.

73. Leon SA, Shapiro B, Sklaroff DM, Yaros MJ. Free DNA in the serum of cancer patients and the effect of therapy. Cancer Res 1977;37:64650

74. Tang JC, Feng YL, Guo T, Xie AY, Cai XJ. Circulating tumor DNA in hepatocellular carcinoma: trends and challenges. Cell Biosci 2016;6:32.

75. Heitzer E, Ulz P, Geigl JB. Circulating tumor DNA as a liquid biopsy for cancer. Clin Chem 2015;61:112-23.

76. Sausen M, Phallen J, Adleff V, Jones S, Leary RJ, Barrett MT, Anagnostou V, Parpart-Li S, Murphy D, Kay Li Q, Hruban CA, Scharpf R, White JR, O'Dwyer PJ, Allen PJ, Eshleman JR, Thompson CB, Klimstra DS, Linehan DC, Maitra A, Hruban RH, Diaz LA Jr, Von Hoff DD, Johansen JS, Drebin JA, Velculescu VE. Clinical implications of genomic alterations in the tumour and circulation of pancreatic cancer patients. Nat Commun 2015;6:7686.

77. Huang Z, Hua D, Hu Y, Cheng Z, Zhou X, Xie Q, Wang Q, Wang F, Du X, Zeng Y. Quantitation of plasma circulating DNA using quantitative PCR for the detection of hepatocellular carcinoma. Pathol Oncol Res 2012;18:271-6.

78. Chen H, Sun L, Zheng H, Zhang Q, Jin X. Total serum DNA and DNA integrity: diagnostic value in patients with hepatitis B virus-related 
hepatocellular carcinoma. Pathology 2012;44:318-24.

79. Mohamed NA, Swify EM, Amin NF, Soliman MM, Tag-Eldin LM, Elsherbiny NM. Is serum level of methylated RASSF1A valuable in diagnosing hepatocellular carcinoma in patients with chronic viral hepatitis C? Arab J Gastroenterol 2012;13:111-5.

80. Sun FK, Fan YC, Zhao J, Zhang F, Gao S, Zhao ZH, Sun Q, Wang K. Detection of TFPI2 methylation in the serum of hepatocellular carcinoma patients. Dig Dis Sci 2013;58:1010-5.

81. Earl J, Garcia-Nieto S, Martinez-Avila JC, Montans J, Sanjuanbenito A, Rodríguez-Garrote M, Lisa E, Mendía E, Lobo E, Malats N, Carrato A, Guillen-Ponce C. Circulating tumor cells (Ctc) and kras mutant circulating free Dna (cfdna) detection in peripheral blood as biomarkers in patients diagnosed with exocrine pancreatic cancer. BMC Cancer 2015;15:797.

82. Kinugasa H, Nouso K, Miyahara K, Morimoto Y, Dohi C, Tsutsumi K, Kato H, Matsubara T, Okada H, Yamamoto K. Detection of K-ras gene mutation by liquid biopsy in patients with pancreatic cancer. Cancer 2015;121:2271-80.

83. Villar S, Le Roux-Goglin E, Gouas DA, Plymoth A, Ferro G, Boniol M, Lereau M, Bah E, Hall AJ, Wild CP, Mendy M, Norder H, van der Sande M, Whittle H, Friesen MD, Groopman JD, Hainaut P. Seasonal variation in Tp53 R249S-mutated serum DNA with aflatoxin exposure and hepatitis B virus infection. Environ Health Perspect 2011;119:1635-40.

84. Kirk GD, Lesi OA, Mendy M, Szymañska K, Whittle H, Goedert JJ, Hainaut P, Montesano R. 249ser TP53 mutation in plasma DNA, hepatitis B viral infection, and risk of hepatocellular carcinoma. Oncogene 2005;24:5858-67.

85. Hosny G, Farahat N, Tayel H, Hainaut P. Ser-249 TP53 and CTNNB1 mutations in circulating free DNA of Egyptian patients with hepatocellular carcinoma versus chronic liver diseases. Cancer Lett 2008;264:201-8.

86. Hu J, Wang Z, Fan J, Dai Z, He Y, Qiu S, Huang X, Sun J, Xiao Y, Song K, Shi Y, Sun Q, Yang X, Shi G, Yu L, Yang G, Ding Z, Gao Q, Tang Z, Zhou J. Genetic variations in plasma circulating DNA of HBV-related hepatocellular carcinoma patients predict recurrence after liver transplantation. PLoS One 2011;6:e26003.

87. García-Fernández N, Macher HC, Rubio A, Jiménez-Arriscado P, Bellido-Díaz ML, Guerrero JM, Molinero P, Bernal-Bellido C, SuárezArtacho G, Gómez-Bravo MA. Detection of p53 mutations in circulating DNA of transplanted hepatocellular carcinoma patients as a biomarker of tumor recurrence. Adv Exp Med Biol 2016;924:25-8.

88. Labgaa I, Villacorta-Martin C, D’Avola D, Craig AJ, von Felden J, Martins-Filho SN, Sia D, Stueck A, Ward SC, Fiel MI, Mahajan M, Tabrizian P, Thung SN, Ang C, Friedman SL, Llovet JM, Schwartz M, Villanueva A. A pilot study of ultra-deep targeted sequencing of plasma DNA identifies driver mutations in hepatocellular carcinoma. Oncogene 2018; doi:10.1038/s41388-018-0206-3.

89. Chan KCA, Lai PBS, Mok TSK, Chan HLY, Ding C, Yeung SW, Lo YMD. Quantitative analysis of circulating methylated DNA as a biomarker for hepatocellular carcinoma. Clin Chem 2008;54:1528-36.

90. Huang ZH, Hu Y, Hua D, Wu YY, Song MX, Cheng ZH. Quantitative analysis of multiple methylated genes in plasma for the diagnosis and prognosis of hepatocellular carcinoma. Exp Mol Pathol 2011;91:702-7.

91. Huang A, Zhang X, Zhou SL, Cao Y, Huang XW, Fan J, Yang XR, Zhou J. Detecting circulating tumor DNA in hepatocellular carcinoma patients using droplet digital PCR is feasible and reflects intratumoral heterogeneity. J Cancer 2016;7:1907-14.

92. Xu RH, Wei W, Krawczyk M, Wang W, Luo H, Flagg K, Yi S, Shi W, Quan Q, Li K, Zheng L, Zhang H, Caughey BA, Zhao Q, Hou J, Zhang R, Xu Y, Cai H, Li G, Hou R, Zhong Z, Lin D, Fu X2, Zhu J, Duan Y, Yu M, Ying B, Zhang W, Wang J, Zhang E, Zhang C, Li O, Guo R, Carter H, Zhu JK, Hao X, Zhang K. Circulating tumour DNA methylation markers for diagnosis and prognosis of hepatocellular carcinoma. Nat Mater 2017;16:1155-61.

93. Chen ZZ, Huang L, Wu YH, Zhai WJ, Zhu PP, Gao YF. LncSox4 promotes the self-renewal of liver tumour-initiating cells through Stat3mediated Sox4 expression. Nat Commun 2016;7:12598.

94. Yuan SX, Wang J, Yang F, Tao Q fei, Zhang J, Wang L li, Yang Y, Liu H, Wang Z guang, Xu Q guo, Fan J, Liu L, Sun SH, Zhou WP. Long noncoding RNA DANCR increases stemness features of hepatocellular carcinoma by derepression of CTNNB1. Hepatology 2016;63:499511.

95. Cao C, Sun J, Zhang D, Guo X, Xie L, Li X, Wu D, Liu L. The long intergenic noncoding RNA UFC1, a target of microRNA 34a, interacts with the mRNA stabilizing protein HuR to increase levels of $\beta$-catenin in HCC cells. Gastroenterology 2015;148:415-26.

96. Guo W, Liu S, Cheng Y, Lu L, Shi J, Xu G, Li N, Cheng K, Wu M, Cheng S, Liu S. ICAM-1-related noncoding RNA in cancer stem cells maintains ICAM-1 expression in hepatocellular carcinoma. Clin Cancer Res 2016;22:2041-50.

97. Wang X, Sun W, Shen W, Xia M, Chen C, Xiang D, Ning B, Cui X, Li H, Li X, Ding J, Wang H. Long non-coding RNA DILC regulates liver cancer stem cells via IL-6/STAT3 axis. J Hepatol 2016;64:1283-94.

98. Zhou CC, Yang F, Yuan S x. I, Ma JZ, Liu F, Yuan JH, Bi FR, Lin KY, Yin JH, Cao GW, Zhou WP, Wang F, Sun SH. Systemic genome screening identifies the outcome associated focal loss of long noncoding RNA PRAL in hepatocellular carcinoma. Hepatology 2016;63:85063.

99. Romano G, Veneziano D, Acunzo M, Croce CM. Small non-coding RNA and cancer. Carcinogenesis 2017;38:485-91.

100. Bala S, Petrasek J, Mundkur S, Catalano D, Levin I, Ward J, Alao H, Kodys K, Szabo G. Circulating microRNAs in exosomes indicate hepatocyte injury and inflammation in alcoholic, drug-induced, and inflammatory liver diseases. Hepatology 2012;56:1946-57.

101. Jiang L, Li X, Cheng Q, Zhang BH. Plasma microRNA might as a potential biomarker for hepatocellular carcinoma and chronic liver disease screening. Tumour Biol 2015;36:7167-74.

102. Raposo G, Stoorvogel W. Extracellular vesicles: exosomes, microvesicles, and friends. J Cell Biol 2013;200:373-83.

103. Théry C, Zitvogel L, Amigorena S. Exosomes: composition, biogenesis and function. Nat Rev Immunol 2002;2:569-79.

104. Yang X, Xie X, Xiao YF, Xie R, Hu CJ, Tang B, Li BS, Yang SM. The emergence of long non-coding RNAs in the tumorigenesis of hepatocellular carcinoma. Cancer Lett 2015;360:119-24.

105. Qiu MT, Hu JW, Yin R, Xu L. Long noncoding RNA: an emerging paradigm of cancer research. Tumor Biol 2013;34:613-20.

106. Lu J, Xie F, Geng L, Shen W, Sui C, Yang J. Investigation of serum IncRNA-uc003wbd and lncRNA-AF085935 expression profile in patients with hepatocellular carcinoma and HBV. Tumor Biol 2015;36:3231-6.

107. Tang J, Zhuo H, Zhang X, Jiang R, Ji J, Deng L, Qian X, Zhang F, Sun B. A novel biomarker Linc00974 interacting with KRT19 promotes proliferation and metastasis in hepatocellular carcinoma. Cell Death Dis 2014;5:e1549. 
108. Jing W, Gao S, Zhu M, Luo P, Jing X, Chai H, Tu J. Potential diagnostic value of lncRNA SPRY4-IT1 in hepatocellular carcinoma. Oncol Rep 2016;36:1085-92.

109. Li SP, Xu HX, Yu Y, He JD, Wang Z, Xu YJ, Wang CY, Zhang HM, Zhang RX, Zhang JJ, Yao Z, Shen ZY. LncRNA HULC enhances epithelial-mesenchymal transition to promote tumorigenesis and metastasis of hepatocellular carcinoma via the miR-200a-3p/ZEB1 signaling pathway. Oncotarget 2016;7:42431-46.

110. Xie H, Ma H, Zhou D. Plasma HULC as a promising novel biomarker for the detection of hepatocellular carcinoma. Biomed Res Int 2013;2013:136106.

111. Lachenmayer A, Alsinet C, Savic R, Cabellos L, Toffanin S, Hoshida Y, Villanueva A, Minguez B, Newell P, Tsai HW, Barretina J, Thung S, Ward SC, Bruix J, Mazzaferro V, Schwartz M, Friedman SL, Llovet JM. Wnt-pathway activation in two molecular classes of hepatocellular carcinoma and experimental modulation by sorafenib. Clin Cancer Res 2012;18:4997-5007.

112. Ma X, Wang X, Yang C, Wang Z, Han B, Wu L, Zhuang L. DANCR acts as a diagnostic biomarker and promotes tumor growth and metastasis in hepatocellular carcinoma. Anticancer Res 2016;36:6389-98.

113. El-Tawdi AHF, Matboli M, El-Nakeep S, Azazy AEM, Abdel-Rahman O. Association of long noncoding RNA and c-JUN expression in hepatocellular carcinoma. Expert Rev Gastroenterol Hepatol 2016;10:869-77.

114. Kamel MM, Matboli M, Sallam M, Montasser IF, Saad AS, El-Tawdi AHF. Investigation of long noncoding RNAs expression profile as potential serum biomarkers in patients with hepatocellular carcinoma. Transl Res 2016;168:134-45.

115. Klingenberg M, Matsuda A, Diederichs S, Patel T. Non-coding RNA in hepatocellular carcinoma: Mechanisms, biomarkers and therapeutic targets. J Hepatol 2017;67:603-18.

116. Coulouarn C, Factor VM, Andersen JB, Durkin ME, Thorgeirsson SS. Loss of miR-122 expression in liver cancer correlates with suppression of the hepatic phenotype and gain of metastatic properties. Oncogene 2009;28:3526-36.

117. Luo J, Chen M, Huang H, Yuan T, Zhang M, Zhang K, Deng S. Circulating microRNA-122a as a diagnostic marker for hepatocellular carcinoma. Onco Targets Ther 2013;6:577-83.

118. Xu J, Wu C, Che X, Wang L, Yu D, Zhang T, Huang L, Li H, Tan W, Wang C, Lin D. Circulating MicroRNAs, miR-21, miR-122, and miR223, in patients with hepatocellular carcinoma or chronic hepatitis. Mol Carcinog 2011;50:136-42

119. Kojima K, Takata A, Vadnais C, Otsuka M, Yoshikawa T, Akanuma M, Kondo Y, Kang YJ, Kishikawa T, Kato N, Xie Z, Zhang WJ, Yoshida H, Omata M, Nepveu A, Koike K. MicroRNA122 is a key regulator of $\alpha$-fetoprotein expression and influences the aggressiveness of hepatocellular carcinoma. Nat Commun 2011;2:338.

120. Tan Y, Ge G, Pan T, Wen D, Chen L, Yu X, Zhou X, Gan J. A serum microrna panel as potential biomarkers for hepatocellular carcinoma related with hepatitis b virus. PLoS One 2014;9:e66577.

121. Ali HEA, Abdel Hameed R, Effat H, Ahmed EK, Atef AA, Sharawi SK, Ali M, Abd Elmageed ZY, Abdel Wahab AH. Circulating microRNAs panel as a diagnostic tool for discrimination of $\mathrm{HCV}$-associated hepatocellular carcinoma. Clin Res Hepatol Gastroenterol 2017;41:e51-62.

122. Zekri ARN, Youssef ASED, El-Desouky ED, Ahmed OS, Lotfy MM, Nassar AAM, Bahnassey AA. Serum microRNA panels as potential biomarkers for early detection of hepatocellular carcinoma on top of HCV infection. Tumor Biol 2016;37:12273-86.

123. El-Tawdi AHF, Matboli M, Shehata HH, Tash F, El-Khazragy N, Azazy AESM, Abdel-Rahman O. Evaluation of circulatory RNA-based biomarker panel in hepatocellular carcinoma. Mol Diagnosis Ther 2016;20:265-77.

124. Okajima W, Komatsu S, Ichikawa D, Miyamae M, Kawaguchi T, Hirajima S, Ohashi T, Imamura T, Kiuchi J, Arita T, Konishi H, Shiozaki A, Moriumura R, Ikoma H, Okamoto K, Taniguchi H, Itoh Y, Otsuji E. Circulating microRNA profiles in plasma: identification of miR-224 as a novel diagnostic biomarker in hepatocellular carcinoma independent of hepatic function. Oncotarget 2016;7:53820-36.

125. Tomimaru Y, Eguchi H, Nagano H, Wada H, Kobayashi S, Marubashi S, Tanemura M, Tomokuni A, Takemasa I, Umeshita K, Kanto T, Doki Y, Mori M. Circulating microRNA-21 as a novel biomarker for hepatocellular carcinoma. J Hepatol 2012;56:167-75.

126. Huang JT, Liu SM, Ma H, Yang Y, Zhang X, Sun H, Zhang X, Xu J, Wang J. Systematic review and meta-analysis: circulating miRNAs for diagnosis of hepatocellular carcinoma. J Cell Physiol 2016;231:328-35.

127. Zhou L, Yang ZX, Song WJ, Li QJ, Yang F, Wang DS, Zhang N, Dou KF. MicroRNA-21 regulates the migration and invasion of a stem-like population in hepatocellular carcinoma. Int J Oncol 2013;43:661-9.

128. Wang J, Li J, Shen J, Wang C, Yang L, Zhang X. MicroRNA-182 downregulates metastasis suppressor 1 and contributes to metastasis of hepatocellular carcinoma. BMC Cancer 2012;12:227.

129. Becker A, Thakur BK, Weiss JM, Kim HS, Peinado H, Lyden D. Extracellular vesicles in cancer: cell-to-cell mediators of metastasis. Cancer Cell 2016;30:836-48.

130. Jia S, Zocco D, Samuels ML, Chou MF, Chammas R, Skog J, Zarovni N, Momen-Heravi F, Kuo WP. Emerging technologies in extracellular vesicle-based molecular diagnostics. Expert Rev Mol Diagn 2014;14:307-21.

131. Wendler F, Favicchio R, Simon T, Alifrangis C, Stebbing J, Giamas G. Extracellular vesicles swarm the cancer microenvironment: from tumor-stroma communication to drug intervention. Oncogene 2017;36:877-84.

132. Witwer KW, Buzás EI, Bemis LT, Bora A, Lässer C, Lötvall J, Nolte-`t Hoen EN, Piper MG, Sivaraman S, Skog J, Théry C, Wauben MH, Hochberg F. Standardization of sample collection, isolation and analysis methods in extracellular vesicle research. J Extracell Vesicles 2013;2:20360.

133. Conde-Vancells J, Rodriguez-Suarez E, Embade N, Gil D, Matthiesen R, Valle M, Elortza F, Lu SC, Mato JM, Falcon-Perez JM. Characterization and comprehensive proteome profiling of exosomes secreted by hepatocytes. J Proteome Res 2008;7:5157-66.

134. Willms A, Müller C, Julich H, Klein N, Schwab R, Güsgen C, Richardsen I, Schaaf S, Krawczyk M, Krawczyk M, Lammert F, Schuppan D, Lukacs-Kornek V, Kornek M. Tumour-associated circulating microparticles: a novel liquid biopsy tool for screening and therapy monitoring of colorectal carcinoma and other epithelial neoplasia. Oncotarget 2016;7:30867-75.

135. Abbate V, Marcantoni M, Giuliante F, Vecchio FM, Gatto I, Mele C, Saviano A, Arciuolo D, Gaetani E, Ferrari MC, Giarretta I, Ardito F, Riccardi L, Nicoletti A, Ponziani FR, Gasbarrini A, Pompili M, Pola R. HepPar1-positive circulating microparticles are increased in subjects with hepatocellular carcinoma and predict early recurrence after liver resection. Int J Mol Sci 2017;18:E1043. 
136. Kornek M, Lynch M, Mehta SH, Lai M, Exley M, Afdhal NH, Schuppan D. Circulating microparticles as disease-specific biomarkers of severity of inflammation in patients with hepatitis C or nonalcoholic steatohepatitis. Gastroenterology 2012;143:448-58.

137. Julich-Haertel H, Urban SK, Krawczyk M, Willms A, Jankowski K, Patkowski W, Kruk B, Krasnodębski M, Ligocka J, Schwab R, Richardsen I, Schaaf S, Klein A, Gehlert S, Sänger H, Casper M, Banales JM, Schuppan D, Milkiewicz P, Lammert F, Krawczyk M, Lukacs-Kornek V, Kornek M. Cancer-associated circulating large extracellular vesicles in cholangiocarcinoma and hepatocellular carcinoma. J Hepatol 2017;67:282-92.

138. Berhane S, Toyoda H, Tada T, Kumada T, Kagebayashi C, Satomura S, Schweitzer N, Vogel A, Manns MP, Benckert J, Berg T, Ebker M, Best J, Dechêne A, Gerken G, Schlaak JF, Weinmann A, Wörns MA, Galle P, Yeo W, Mo F, Chan SL, Reeves H, Cox T, Johnson P. Role of the GALAD and BALAD-2 serologic models in diagnosis of hepatocellular carcinoma and prediction of survival in patients. Clin Gastroenterol Hepatol 2016;14:875-86.e6. 